\title{
Going Organic Changes Weed Population Dynamics
}

Mathieu Ngouajio ${ }^{1}$ and Milton E. McGiffen, Jr. ${ }^{2}$

\begin{abstract}
Additional index words. species richness, soil properties, weed suppression, weed seed, cover crops, organic amendments, compost, soil quality, allelopathy, chemotaxis

SummarY. Organic agriculture is growing in importance worldwide. In the United States, the rate of increase of organic growers was estimated at $12 \%$ in 2000 . However, many producers are reluctant to undertake the organic transition because of uncertainty of how organic production will affect weed population dynamics and management. The organic transition has a profound impact on the agroecosystem. Changes in soil physical and chemical properties during the transition often impact indirectly insect, disease, and weed dynamics. Greater weed species richness is usually found in organic farms but total weed density and biomass are often smaller under the organic system compared with the conventional system. The improved weed suppression of organic agriculture is probably the result of combined effects of several factors including weed seed predation by soil microorganisms, seedling predation by phytophagus insects, and the physical and allelopathic effects of cover crops.
\end{abstract}

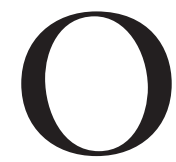

rganic farming systems have grown tremendously during the last 20 years. Nationwide estimates indicate that total retail sales of organic food increased from $\$ 78$ million in 1980 to $\$ 7.7$ billion in 2000 [California Certified Organic Farmers (CCOF), 2001]. The number of organic farmers in the U.S. is increasing steadily at an annual rate of $12 \%$ [U. S. Department of Agriculture (USDA), 2001]. In 2000, there were 12,200 organic farmers in the U. S., most of whom are small-scale producers (USDA, 2001). In California, the number of organic farms has doubled in 8 years, with more than 2,600 certified organic growers registered in 1999 (CCOF, 2001). The growth in importance of organic crop production systems has been fueled by growing concerns of the effects of conventional production systems on the environment, health, and economics (Batte et al., 1993; Bond et al., 1998; Buys, 1993; Liebman and Davis, 2000). Pest resistance to agrochemicals, effects of those chemicals on nontarget organisms and sites; and their potential hazards to human health have posed serious challenges for conventional agricultural production systems and increased the demand for organic produce among consumers. The higher prices commanded by organic produce and the low external input nature of organic farming systems have created economic incentives for organic production. With the important growth of organic farming, there is a pressing need for more research-based information on production and handling of organic produce.

\footnotetext{
${ }^{1}$ Assistant professor of vegetable crops and corresponding author, Department of Horticulture, Michigan State University, East Lansing, Michigan USA 48824-1325; ngouajio@msu.edu.

${ }^{2}$ Extension specialist, Department of Botany and Plant Science, University of California, Riverside, California USA 92521-0124;
} milt@citrus.ucr.edu. 
The revised national standards for the production, handling, and processing of organically grown agricultural products were announced on $20 \mathrm{Dec}$. 2000, with full implementation on 19 Feb. 2001 (USDA, 2001). Organic farming systems preclude the use of synthetic pesticides and fertilizers (USDA, 2001). Weeds, insect pests, and pathogens are controlled using naturally occurring biocides and cultural methods. Soil fertility is maintained with compost, animal manure, green manure, crop residues, cover crop residues, and other organic amendments. Also, the new standards require that any field or farm parcel from which harvested crops are intended to be sold, labeled, or represented as organic, must have had no prohibited substance applied for 3 years immediately preceding harvest of the crop (USDA, 2001). This 3-year period of following organic rules before the produce can be sold under the organic label is usually referred to as the organic transition or conversion phase.

Conversion from conventional to organic farming system creates major changes in the agroecosystem that affect pest population dynamics. Organic pest management has been a subject of intense debate over the last decade. Weed management is the top priority of organic growers (Organic Farming Research Foundation, 2001) and the major limitation to organic conversion (Davies et al., 1997). The objectives of this paper are to 1) review changes in the agroecosystem associated with the conversion from conventional to organic farming system, 2) evaluate weed problems under both conventional and organic system, and 3) determine the factors that can change weed population dynamics under organic systems.

\section{Changes in}

\section{agroecosystems} associated with conversion to organic farming systems

Changes in crop management systems affect pest population dynamics (Buhler, 1995; Drinkwater et al., 1995; $\mathrm{Li}$ and Kremer, 2000). The use of synthetic fertilizers for plant mineral nutrition and synthetic pesticides for pest management in conventional farming systems may lead to a reduction in soil organic matter, weeds, arthropods, and microbial diversity. The reduction of soil microorganisms coupled with low diversity creates a less robust environ-

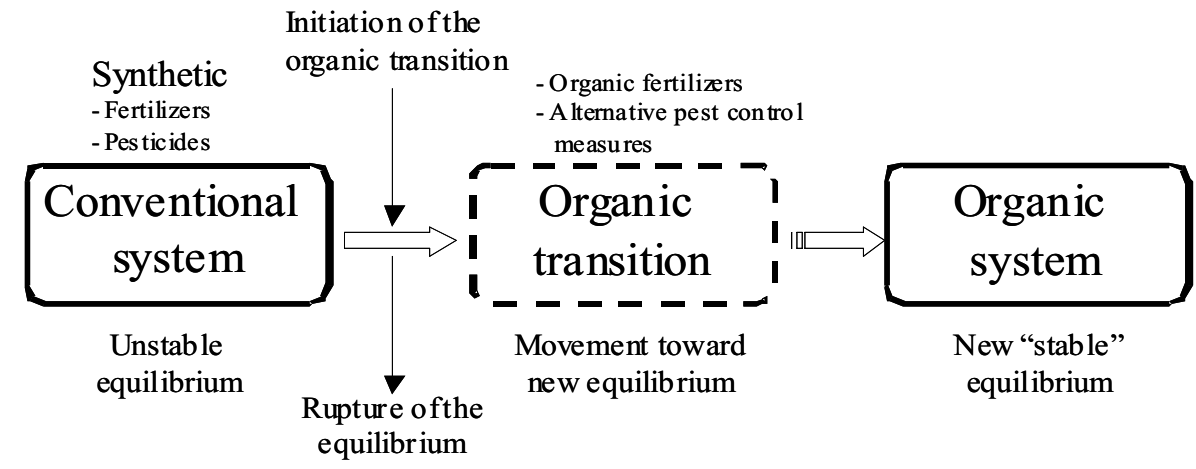

Fig. 1. The change in the agroecosystem equilibria during the conversion from conventional to organic farming systems. Each equilibrium state is dynamic and not static.

ment (Fig. 1). The conversion to organic systems ruptures the initial equilibrium state of the agroecosystem (Drinkwater et al., 1995) and a dynamic transition is initiated towards a new, more stable equilibrium (Fig. 1).

Soil fertility in the transition to organic systems can be maintained with using crop rotation, cover crops, improved crop residue management, and application organic soil amendments such as compost and animal manure. Soil fertility management during the transition to organic farming systems creates important changes in soil physical, chemical, and biological properties. Because of their seed bank and lack of ability to move, weed populations are highly affected by changes in soil conditions.

\section{Going organic changes soil physical, chemical, and biological properties}

Changes in soil physical properties (Table 1) during the conversion to organic systems include better soil aeration and rooting depth, increased aggregate stability and water holding capacity, reduced soil erosion potentials and soil compaction (Cuevas etal., 2000; Drinkwater et al., 1995; Macrae and Mehuys, 1987; Magdoff and van Es, 2000; Ozores-Hampton, 1998; Parr and Willson, 1980).

Changes in soil chemical properties associated with organic farming systems have been investigated only recently (Astier et al., 1994; Brosius et al., 1998; Cuevas et al., 2000; Drinkwater et al., 1995; White et al., 1997). In a comparative study of organic and conventional agroecosystems conducted on commercial farms in the Central Valley of California, Drinkwater et al. (1995) observed a strong relationship between crop management and soil chemical properties. A progressive change in soil chemical properties was found during the transition phase. Soil $\mathrm{pH}$ changed from 6.4 (in the conventional system) to 6.8 (in the organic system) in 3 years or less in the organic transition, and to 7.4 after more than 3 years in the organic transition. In 3 years or less into the transition, soil organic matter increased from $0.98 \%$ to $1.11 \%$, total Kjeldahl nitrogen $(\mathrm{N})$ increased from $0.086 \%$ to $0.094 \%$, and the proportion of ammonium $\left(\mathrm{NH}_{4}^{+}\right)$in total inorganic $\mathrm{N}$ increased from $3.4 \%$ to $8.9 \%$. Brosius et al. (1998) reported similar observations with organic soil amendments. Changes in soil conditions during the transition to organic farming systems usually require several years before becoming apparent (Cuevas et al., 2000; Drinkwater et al., 1995; White et al., 1997).

Climatic conditions may play a decisive role in the soil changes that occur during the transition to organic production. An experiment conducted in Madrid (Spain) under semiarid conditions showed no significant change in soil organic matter, $\mathrm{pH}$, total $\mathrm{N}$ and cation exchange capacity (CEC) 1 year after application of $120 \mathrm{t} \cdot \mathrm{ha}^{-1}$ ( 48 tons / acre) of municipal waste compost (Cuevas et al., 2000). Organic matter breakdown is usually very fast when high temperatures increase microbial activity. We observed complete decomposition of cowpea (Vigna unguiculata) residue $45 \mathrm{~d}$ after incorporation into the soil at the end of summer in the Coachella Valley desert in California (unpublished data). Daily average temperatures are usually above $30{ }^{\circ} \mathrm{C}\left(86^{\circ} \mathrm{F}\right)$ during summer in the low desert. Under such conditions, large amounts of organic amendments are required for significant changes in soil properties. 
Table 1. Effects of conversion to organic farming systems on soil properties. ${ }^{\mathrm{z}}$

\begin{tabular}{|c|c|c|}
\hline Factor & Effect & Reference \\
\hline \multicolumn{3}{|l|}{ Soil physical properties } \\
\hline Bulk density & Decrease & Macrae and Mehuys, 1987 \\
\hline Water-holding capacity & Increase & Magdoff and van Es, 2000; Parr and Willson, 1980 \\
\hline Aggregates & Stabilize & Macrae and Mehuys, 1987; Magdoff and van Es, 2000 \\
\hline Aeration & Increase & Magdoff and van Es, 2000 ;Parr and Willson, 1980 \\
\hline Rooting depth & increase & Parr and Willson, 1980 \\
\hline Crusting & Decrease & Parr and Willson, 1980 \\
\hline Runoff & Decrease & Parr and Willson, 1980 \\
\hline \multicolumn{3}{|l|}{ Soil chemical properties } \\
\hline $\mathrm{pH}$ & Increase & Brosius et al., 1998; Drinkwater et al., 1995; Maynard, 2000 \\
\hline Cation exchange capacity & Increase & Brosius et al., 1998 \\
\hline Organic matter & Increase & Drinkwater et al., 1995; Magdoff and van Es, 2000; Maynard, 2000 \\
\hline Total carbon & Increase & Brosius et al., 1998; Drinkwater et al., 1995 \\
\hline $\mathrm{N}$ mineralization potential & Increase & Drinkwater et al., 1995 \\
\hline Total Kjeldahl nitrogen $(\mathrm{N})$ & Increase & Drinkwater et al., 1995 \\
\hline Proportion of ammonium in total inorganic $\mathrm{N}$ & Increase & Drinkwater et al., 1995 \\
\hline Available potassium and phosphorous & increase & Cuevas et al., 2000; Drinkwater et al., 1995 \\
\hline Electrical conductivity & Decrease & Drinkwater et al., 1995 \\
\hline Inorganic $\mathrm{N}$ content & Increase & Drinkwater et al., 1995 \\
\hline Nitrate & Decrease & Brosius et al., 1998 \\
\hline \multicolumn{3}{|l|}{ Soil biological properties } \\
\hline Actinomycetes & Increase & Brosius et al., 1998; Drinkwater et al., 1995 \\
\hline Total bacteria & Increase & Brosius et al., 1998; Cohen et al., 1998; Drinkwater et al., 1995 \\
\hline \multirow[t]{2}{*}{ Total fungus } & Increase & Valdrighi et al.,1996 \\
\hline & Decrease & Drinkwater et al., 1995 \\
\hline Soils microbes & Increase & Astier et al., 1994; Brosius et al., 1998; Cohen et al., 1998 \\
\hline
\end{tabular}

${ }^{\mathrm{z}}$ Results from experiments comparing conventional and organic farming systems or experiments comparing conventional soils and soils amended with organic matter such as compost, animal, and green manure.

Soil microorganisms play a key role in nutrient cycling, plant nutrition, xenobiotic transformations, and interaction with other soil dwelling organisms (Gallardo and Schlesinger, 1995; Kremer, 1998; Li and Kremer, 2000; Valdrighi et al., 1996). Switching from a conventional to organic farming system changes not only the total microorganism community in the soil, but also the relative abundance of individual species (Drinkwater et al., 1995; Li and Kremer, 2000). Li and Kremer (2000) found an increase in the populations of deleterious rhizobacteria under organic and other cropping systems that favor high organic matter accumulation in the soil. During the organic transition phase, Drinkwater et al. (1995) observed an increase in both total biomass and species composition of actinomycetes population (Table 2). Using the ability of the actinomycetes to hydrolyze starch, hemicellulose, and cellulose, they show a significant difference in species composition for communities isolated from organic and conventional soil. Compost derived humic acid was also shown to increase soil bacterial biomass (Valdrighi et al., 1996), especially for ammonia and nitrite-oxidizing autotrophic bacteria. Gallardo and Schlesinger (1995) showed that low organic carbon content of desert soil was the most limiting factor for soil microbial activity.

\section{Going organic changes plant species diversity}

Farming practices have important effects on landscape visual quality. Neighbors, visitors, and others often prefer the aesthetic appearance of organic farms (Hald, 1999; Hendriks et al., 2000). Conversion to organic farming systems usually increases plant species diversity (Hald, 1999; Van Elsen, 2000). New

Table 2. Effects of conversion to organic farming system on insect and plant populations. $^{\mathrm{z}}$

\begin{tabular}{|c|c|c|}
\hline Factor & Effect & Reference \\
\hline \multicolumn{3}{|l|}{ Insect population } \\
\hline Total insect population & Constant & Drinkwater et al., 1995 \\
\hline Natural enemies & Increase & Drinkwater et al., 1995 \\
\hline Egg laying ability & Decrease & Phelan et al., 1995 \\
\hline \multicolumn{3}{|l|}{ Plant population } \\
\hline Landscape quality & Improve & Hendriks et al., 2000 \\
\hline Species richness & Increase & Hald, 1999; Van Elsen, 2000 \\
\hline Wild species biomass & Increase & Hald, 1999 \\
\hline
\end{tabular}

${ }^{\mathrm{z}}$ Results from experiments comparing conventional and organic farming systems or experiments comparing conventional soils and soils amended with organic matter such as compost, animal, and green manure. 


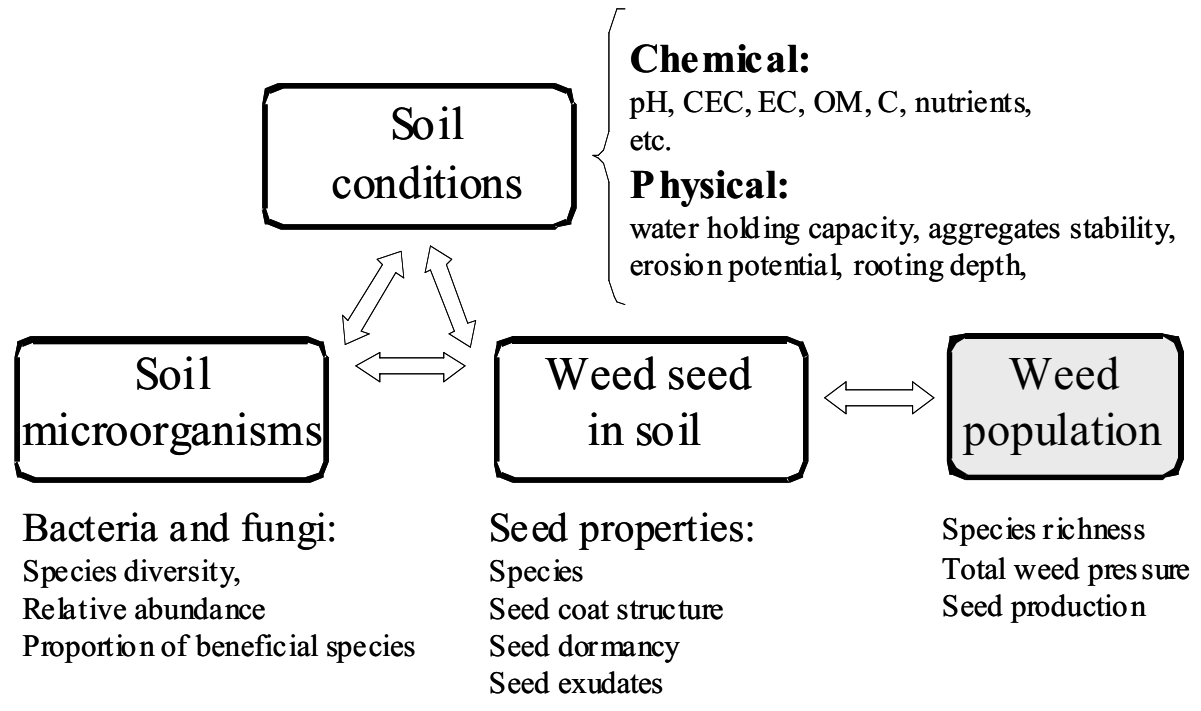

Fig. 2. Weed population as a result of the interaction between soil conditions, weed seeds, and soil microorganisms. $\mathrm{CEC}=$ cation exchange capacity, $\mathrm{EC}=$ electrical conductivity, $\mathbf{O M}=$ organic matter, and $\mathbf{C}=$ carbon.

the weed flora observed at a given place and time in the field. The effect of organic transition on weed population has not been adequately researched. However, there are several reports of higher species richness and lower total weed populations under organic farming systems (Hald, 1999; Kremer, 1998; Kremer, 1993; Li and Kremer, 2000; Liebman and Davis, 2000; Van Elsen, 2000).

Several investigators have reported increased wild plant species richness under organic farming systems (Hald, 1999; Van Elsen, 2000). In Denmark (Hald, 1999), 29 weed species were recorded in cereal fields grown under organic system, and only 11 species in conventional fields. While species diversity was more uniform on organic farms, there was a further reduction in the number of weed species in conventional farming system from margins to midfield. Similar results were reported in Europe (Van Elsen, 2000) for root crop fields managed organically compared with crops managed conventionally. In field margins, Van Elsen (2000) found an average of 25 species in organic farms, compared with 16 species in con- ventional farms. The difference between organic and conventional was more pronounced in the interior of the farms, with 18 and 3 species in organically and conventionally managed farms, respectively.

The increase of weed species richness observed under organic farming systems does not automatically mean increased weed population or greater crop yield loss. Cover crops have been shown to reduce weed densities in the northeastern U.S. (Teasdale, 1998). In Stillwater, Maine, Liebman and Davis (2000) reported reduced weed biomass when barley (Hordeum vulgare) fields were intercropped with red clover (Trifolium pratense). Cover crop residue used as surface mulch is known to prevent light penetration, thereby reducing weed seed germination (Hutchinson and McGiffen, 2000; Teasdale, 1998). In the Coachella Valley of California, we observe a 10 -fold reduction in weed populations with summer cowpea cover crop used as surface mulch in fall lettuce (Lactuca sativa) compared to a bare ground summer fallow (unpublished data). Total weed biomass and weed densities are reduced with the cowpea mulch system. Cover crops have been implicated in weed suppression through allelopathic interactions (Liebman and Davis, 2000; Liebman and Ohno, 1998; Teasdale, 1998). Residues of cover crop species including winter rye (Secale cereale), sunflower (Helianthusannuns), oat (Avena sativa), wheat (Triticum aestivum), sorghum (Sorghum bicolor), hairy vetch (Vicia villosa), red clover, and alfalfa (Medicago sativa) are toxic to weeds (Liebman and Ohno, 1998). Legume cover crops have also been implicated in weed suppression by delaying $\mathrm{N}$ release to weeds compared to synthetic fertilizers (Liebman and Ohno, 1998). When residues of cover crops are incorporated into the soil, the combined effects of allolepathy and nutrient delay contribute to significant reduction in weed infestations.

Organic soil amendments have been shown to reduce the need for weed control in several vegetable crops (Ozores-Hampton, 1998). In Presque Isle, Maine, Liebman and Davis (2000) reported reduced weed biomass in potato (Solanum tuberosum) fields after amending with compost or green manure. Organic soil amendments are important components of plant nutrition in organic farming. Crop residues, cover crop residues, and compost are common sources of organic matter. The effect of increased soil organic matter on weed populations in organic systems is time-dependent. Weed suppressive effects are generally not observed during the first year of organic transition. In an experiment conducted in the Coachella Valley desert in California, we observed no difference in weed population between the conventional and the organic system during the first year in the organic transition (Fig. 2). However, during the second year, the combined populations of all weed species were reduced $42 \%$ in the organic plots. After 1 year in the same study, the amount of organic matter and microbial biomass increased in the organic system compared with the conventional system (Table 3 ). In

Table 3. Changes in soil chemical and biological properties after 1 year in the organic farming system transition.

\begin{tabular}{|c|c|c|c|c|}
\hline $\begin{array}{l}\text { Farming } \\
\text { system }^{\mathrm{z}}\end{array}$ & $\begin{array}{c}\text { Organic } \\
\text { matter } \\
(\%)\end{array}$ & 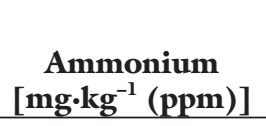 & $\begin{array}{c}\text { Bacteria } \\
\text { Nitrate } \\
{\left[\mathrm{mg} \cdot \mathrm{kg}^{-1}(\mathrm{ppm})\right]}\end{array}$ & $\begin{array}{c}\text { biomass } \\
{\left[\text { wt carbon/wt soil }\left(\mathrm{mg}^{-1} \cdot \mathrm{g}^{-1}\right)\right]}\end{array}$ \\
\hline Conventional & 0.76 & 5.70 & 119 & 0.50 \\
\hline Organic & 1.15 & 12.28 & 226 & 0.70 \\
\hline
\end{tabular}

${ }^{2}$ Data collected at melon harvest. Crop rotations were 1) summer cowpea (Vigna unguiculata), fall lettuce (Lactuca sativa), and spring melon (Cucumis melo) for the organic system and 2) summer fallow, fall lettuce, and spring melon for the conventional system. Synthetic fertilizers were replaced by compost in the organic system. $1.00 \mathrm{mg} \cdot \mathrm{g}^{-1}=$ 1,000 ppm. 


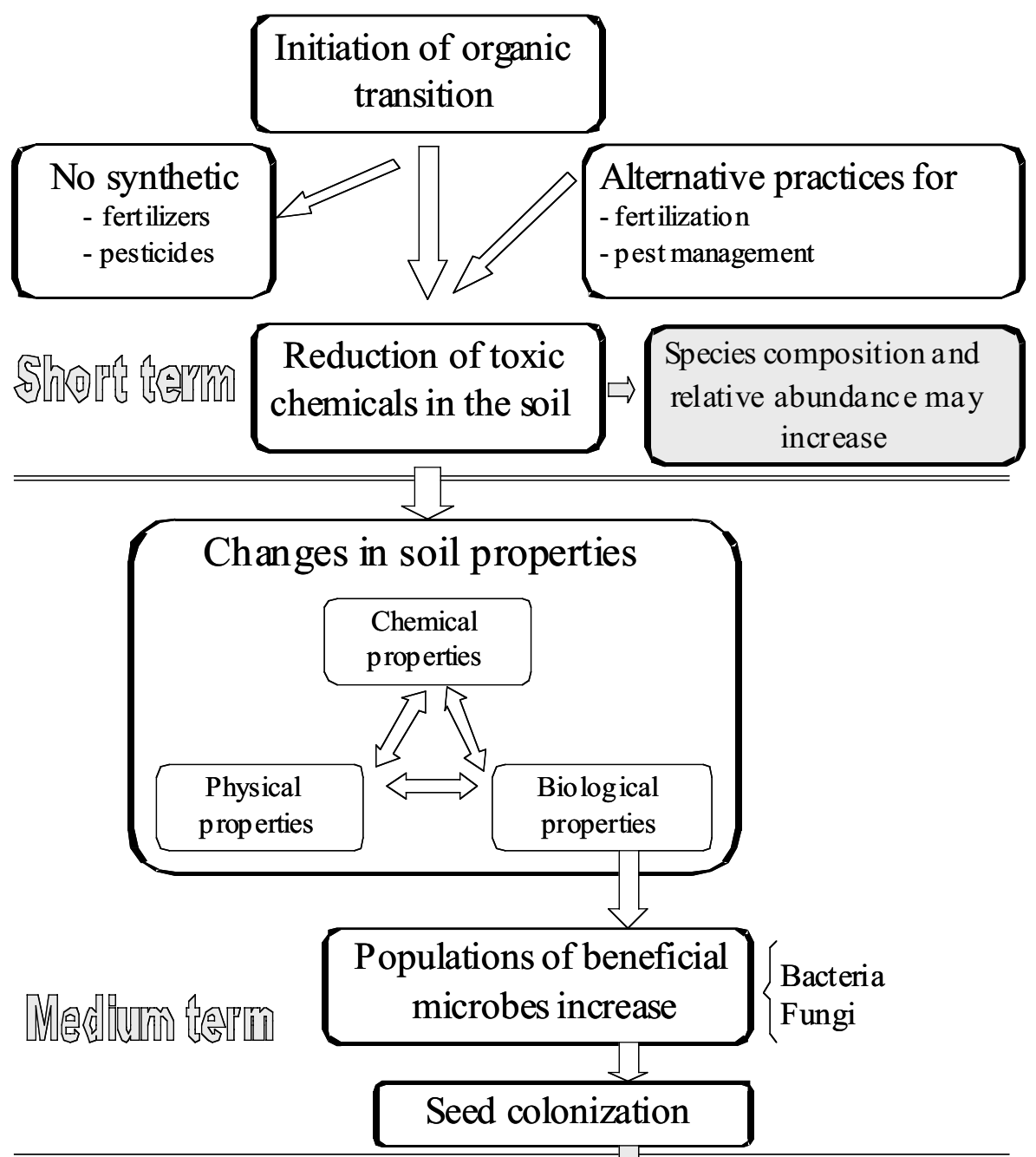

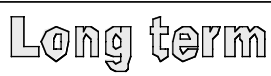

Seedbank depletion

Fig. 3. Factors contributing to changes in weed population dynamics following conversion to organic farming systems.

the organic system, soil organic matter increased by $51 \%$ and bacterial biomass increased by $40 \%$ compared to the conventional system. Simultaneous decreases in weed populations and increases of microbial activity suggest that microbes are depleting weed seedbank by feeding on weed seeds or seedlings (Kremer, 1998; Li and Kremer, 2000).

\section{Factors associated with changes in weed population dynamics under organic production systems}

The effect of a change in the agroecosystem on weed population dynamics is well perceived by scientists and most growers. However, the exact mechanisms involved in some of the changes in weed populations are yet to controlled by herbicide applications during the growing season, and herbicide residues that remain in the soil during the off-season. Over time there is significant depletion of seed of those species in the soil. The species richness in field borders grown under conventional systems can explain this effect (Hald, 1999; van Elsen, 2000). Incoming seeds are more likely to invade field borders than midfields.

The transition from conventional to organic farming systems alters soil physical, chemical, and biological properties (Astier et al., 1994; Brosius et al., 1998; Buhler, 1995; Cuevas et al., 2000; Drinkwater et al., 1995; Li and Kremer, 2000; Liebman and Davis, 2000; Macrae and Mehuys, 1987; Magdoff and van Es, 2000; Parr and Willson, 1980; White et al., 1997). Soil conditions determine the fate of weed seeds in the soil (Liebman and Davis, 2000; Kremer, 1998 and 1993 ) (Fig. 3). This in turn determines the importance of the weed seedbank and the emerging weed seedlings. Appropriate management of both soil and weed are therefore required for sustainable weed management strategies. High microbial activity is typical of most soils under organic farming system (Table 3 ) and has the effect of increasing seed attack by beneficial microbes, followed by seed mortality, decay, and seedbank depletion (Kremer, 1998 and 1993; $\mathrm{Li}$ and Kremer, 2000) (Fig. 4).

Microorganisms are attracted to exudates diffused from weed seeds, a process called chemotaxis (Kremer, 1993; Begonia, 1989). Within 24 h, some bacteria actively migrated in the soil from the inoculation site to the seed placed $2 \mathrm{~cm}$ ( 0.79 inches) away (Begonia, 1989). In the control soil (without seed) the migration distance was smaller, even $72 \mathrm{~h}$ after inoculation. The selective attraction of certain groups of microbes by weed seeds may explain why there are usually intimate microbial associations with seeds in the soil (Kremer, 1998). In a study with redroot pigweed (Amaranthus retroflexus), giant foxtail (Setaria faberii), and velvetleaf (Abutilon theophrasti) seeds, both fungal and bacterial associations were observed, with up to three species of microbes per seed (Kremer, 1998). Several of those microorganisms reduced seedling root growth by $85 \%$ for bacteria and $69 \%$ for fungi (Kremer, 1998). In 


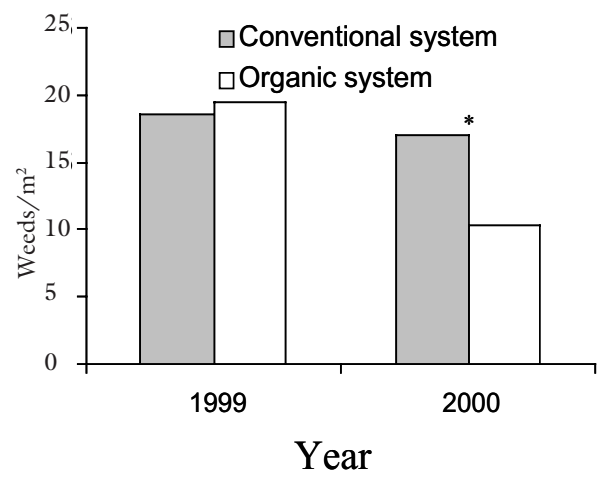

Fig. 4. The effect of crop management system on weed populations in lettuce (Lactuca sativa). Data collected at lettuce harvest. A bare ground summer fallow was used in all systems. The star $\left(^{*}\right)$ indicates that there were significantly more weeds in the conventional system than in the organic system in 2000; 1 $\mathrm{m}^{2}=10.8 \mathrm{ft}^{2}$.

a similar study, velvetleaf seedling emergence and seed viability was reduced when the soil was inoculated with bacteria isolates (Begonia, 1989; Kremer, 1993).

The results presented above clearly indicate that changes in the soil properties caused by organic management are closely associated with changes in weed population dynamics. The mechanisms that reduce weed populations under organic farming systems can be conceptualized in terms of whole agroecosystem change. Initiation of the organic transition starts with the suspension of synthetic fertilizers and pesticides and use of organic soil amendments and alternative pest management strategies. The high selection pressure imposed by herbicides and other management practices is lifted, creating the appropriate environment for highly susceptible plant species (Hald, 1999). This leads to increased diversity in plant species. The use of compost and manure amendment, cover crops and other low external input management practices create a change in soil physical, chemical and biological properties. Both soil organic matter content and soil $\mathrm{pH}$ increase, creating a favorable environment for soil microbes. Soil microbial communities and the relative importance of individual community increase. Beneficial microbes (mostly bacteria and fungi) increase colonization of weed seeds, causing their death and decay. Ultimately, the weed seedbank is depleted. Elimination of insecticides in the organic system has the effect of increasing the populations of phytophagus insects. Those insects feed on weed seedlings as alternate source of food, therefore reducing weed populations. Under organic systems, there is therefore a double effect on weed population reduction: Weed seed predation by insects and soil dwelling microorganisms, and weed seedling predation by phytophagus arthropods.

\section{Literature cited}

Astier, M., P.L. Gersper, and M. Buchanan. 1994. Combining legumes and compost: A viable alternative for farmers in conversion to organic agriculture. Compost Sci. Utilization 2:80-87.

Batte, M.T., D.L. Forster, and F.J. Hitzhusen. 1993. Organic agriculture in Ohio: An economic perspective. J. Prod. Agr. 6:536-542.

Begonia, M.F.T. 1989. Characterization of attraction of rhizobacteria to weed seeds and seedlings. PhD Diss. Univ. MO., Columbia.

Bond, W., H.C. Moore, R.J. Atkinson, J.R. Bevan, and M.E.K. Lennartsson. 1998. Changes in the weed seedbank following different weeding treatments in drilled salad onion and carrot crops grown in organic and conventional systems. Biol. Agr. Hort. 16:203-215.

Brosius, M.R., G.K. Evanylo, L.R. Bulluck, and J.B. Ristano. 1998. Comparison of commercial fertilizer and organic by-products on soil chemical and biological properties and vegetable yields, p. 195-202. In: S. Brown, J.S. Angle, and L. Jacobs (eds.). Beneficial co-utilization of agricultural, municipal and industrial by-products. Kluwer Academic Publ., Dordrecht, The Netherlands.

Buhler, D.D. 1995. Influence of tillage systems on weed population dynamics and management in corn and soybean in the central USA. Crop Sci. 35:1247-1258.

Buys, J. 1993. Conversion towards organic agriculture in Russia: A preliminary study. Biol. Agr. Hort. 10:125-140.

California Certified Organic Farmers. 2001. Press release: California Certified Organic Farmers (CCOF) Santa Cruz, Calif., 20 Dec. 2000. 18 Aug. 2001. <http:// www.ccof.org/pr_usdastand.htm>.

Cohen, R., B. Chefetz, and Y. Hadar. 1998. Suppression of soil-borne pathogens by composted municipal solid waste, p. 113-130. In: S. Brown, J.S. Angle, and L. Jacobs (eds.). Beneficial co-utilization of agricultural, municipal and industrial by-products. Kluwer Academic Publ.,
Dordrecht, The Netherlands.

Cuevas, G., R. Blazquez, F. Martinez, and I. Walter. 2000. Composted MSW effects on soil properties and native vegetation in a degraded semiarid shrubland. Compost Sci. Utilization 8:303-309.

Davies, D.H.K., A. Christal, M. Talbot, H.M. Lawson, and G. McN Wright. 1997. Changes in weed population in the conversion of two arable farms to organic farming. Proc. British Crop Prot. Conf.: Weeds 1-3:973-978.

Drinkwater, L.E., D.K. Letourneau, F. Workneh, A.H.C. Van Bruggen, and C. Shennan. 1995. Fundamental differences between conventional and organic tomato agroecosystems in California. Ecol. Appl. 5:1098-1112.

Gallardo, A. and W.H. Schlesinger. 1995. Factors determining soil microbial biomass and nutrient immobilization in desert soils. Biogeochemistry 28:55-68.

Hald, A.B. 1999. Weed vegetation (wild flora) of long established organic versus conventional cereal fields in Denmark. Ann. Appl. Biol. 134:307-314.

Hendriks, K., D.J. Stobbelaar, and J.D. van Mansvelt. 2000. The appearance of agriculture: An assessment of the quality of landscape of both organic and conventional horticultural farms in West Friesland. Agr. Ecosystems Environ. 77:157-175.

Hutchinson, C.M. and M.E. McGiffen, Jr. 2000. Cowpea cover crop mulch for weed control in desert pepper production. HortScience 35:196-198.

Kremer, R.J. 1998. Microbial interactions with weed seeds and seedlings and its potential for weed management, p. 161-179. In: J.L. Hatfield, D.D. Buhler, and B.A. Stewart (eds.). Integrated weed and soil management. Ann Arbor Press, Chelsea, Mich.

Kremer, R.J. 1993. Management of weed seed banks with microorganisms. Ecol. Appl. 3:42-52.

Li, J. and R.J. Kremer. 2000. Rhizobacteria association with weed seedlings in different cropping systems. Weed Sci. 48:734741 .

Liebman, M. and A.S. Davis. 2000. Integration of soil, crop and weed management in low-external-input farming systems. Weed Res. 40:27-47.

Liebman M. and T. Ohno. 1998. Crop rotation and legume residue effects on weed emergence and growth: Applications for weed management, p. 198-221. In: J.L. Hatfield, D.D. Buhler, and B.A. Stewart (eds.). Integrated weed and soil management. Ann Arbor Press, Chelsea, Mich. 
Macrae, R.J. and G.R. Mehuys. 1987. Effects of green manuring in rotation with corn on the physical properties of two Quebec [Canada] soils. Biol. Agr. Hort. 4:257-270.

Magdoff, F. and H. Van Es. 2000. Building soils for better crops. 2nd ed. Sustainable Agr. Network Hdbk. Ser. Book 4. Sustainable Agr. Network, Beltsville, Md.

Maynard, A.A. 2000. Applying leaf compost to reduce fertilizer use in tomato production. Compost Sci. Utilization 8:203-209.

Organic Farming Research Foundation. 2001. Final results of the third biennial national organic farmers' survey. 18 Aug. 2001. <http://www.ofrf.org/publications/survey/1997.html>.

Ozores-Hampton, M. 1998. Compost as an alternative weed control method. HortScience 33:938-940.

Parr, J.F. and G.B. Willson. 1980. Recycling organic wastes to increase soil productivity. HortScience 15:162-166.

Phelan, P.L., J.F. Mason, and B.R. Stinner. 1995. Soil-fertility management and host preference by European corn borer, Ostrinia nubilalis(Hubner), on Zea mays
L.: A comparison of organic and conventional chemical farming. Agr. Ecosystems Environ. 56:1-8.

Teasdale, J.R. 1998. Cover crops, smother plants, and weed management, p. 247270. In: J.L. Hatfield, D.D. Buhler, and B.A. Stewart (eds.). Integrated weed and soil management. Ann Arbor Press, Chelsea, Mich.

United States Department of Agriculture. 2001. News release: Gickman announces national standards for organic food. 18 Aug. 2001. <http://www.usda.gov/ news/releases/2000/12/0425.htm>.

Valdrighi, M.M., A. Pera, M. Agnolucci, S. Frassinetti, D. Lunardi, and G. Vallini. 1996. Effects of compost-derived humic acids on vegetable biomass production and microbial growth within a plant (Cichorium intybus)-soil system: A comparative study. Agr. Ecosystems Environ. 58:133-144.

Van Elsen, T. 2000. Species diversity as a task for organic agriculture in Europe. Agr. Ecosystems Environment 77:101-109.

White, C.S., S.R. Loffin, and R. Aguilar. 1997. Application of biosolids to degraded semiarid rangeland: Nine-year responses. J. Environ. Qual. 26:1663-1671. 